\title{
Title:
}

\section{A Critical Appraisal of Predatory Journals in Pathology}

Yaman M. AlAhmad ${ }^{1 \#}$, Ibrahim Abdelhafez ${ }^{1 \#}$, Farhan S. Cyprian ${ }^{1}$, Faruk Skenderi ${ }^{2}$,

${ }^{1}$ College of Medicine, Qatar University, Doha, Qatar

${ }^{2}$ Department of Pathology, Clinical Center, University of Sarajevo, Sarajevo, Bosnia and

\# These authors contributed equally

*Correspondence:

Semir Vranic, MD, PhD

Phone: +974 44037873 


\section{Abstract}

Predatory or pseudo journals have recently come into focus due to their massive internet expansion and extensive spam email soliciting. Recent studies explored this urging problem in several biomedical disciplines. In the present study, we identified 69 potential predatory (pseudo) pathology journals that were contrasted to 89 legitimate pathology journals obtained from the major bibliographic databases. All potential predatory journals in pathology shared at least one of the features proposed by previous studies (e.g. a poor web-site integrity, submissions via email, unclear or ambiguous peerreview process, missing names of the editorial board members, missing or pending the journal ISSN). Twenty-one (30\%) of the potential predatory pathology journals had Reports.

Key words: academic publishing - journals - predatory journals - legitimate journals - 


\section{Introduction}

Predatory or pseudo journals refer to journals that recruit articles through aggressive marketing and spam emails, promising quick, but not robust review and fast open-access (OA) publication, thus compromising scholarly publishing standards (1-4). Their key motive is a financial benefit via article processing charges (APCs) and other additional fees $(1,3,4)$.

The number of OA journals has dramatically risen over the past fifteen years (5), reaching 11,376 journals, indexed in the Directory of Open Access Journals (DOAJ) in 2018 (available at https://doaj.org). This expansion was parallel to the increase in the number of predatory publishers from 18 in 2011 to more than 1100 in $2016(6,7)$. Predatory (pseudo) journals have become more prevalent than ever due to massive internet expansion and extensive spam email soliciting $(2,4,8)$. These journals are Colorado Denver, posted his first list of potential predatory, OA publishers and journals (available at: https://beallslist.weebly.com), predatory journals have come into focus (3, 4).

Recent studies have highlighted the significant impact of potentially predatory journals in several biomedical fields including neuroscience/neurology, urology, emergency medicine, physical medicine, orthopedics, anesthesiology and pediatrics (9- 
neurosciences, and 20.2\% for neurology). By April 2017, these values increased to $23.7 \%$ for rehabilitation, $16.1 \%$ for neuroscience, and $24.7 \%$ for neurology, indicating that these journals evolved rapidly $(6,7)$. The study on emergency medicine revealed that almost half $(25 / 55)$ of the OA journals were predatory journals (12). Furthermore, the study on urology found that (7/32) potential predatory journals, which were solicited to an academic urologist, were indexed in reputable databases including: Journal Citation Reports (JCR), Scimago Journal Rankings (SJR), and DOAJ (13). In contrast, a recent study of Kokol et al. exploring predatory journals in pediatrics revealed 26 such journals; however, none of them were indexed in PubMed, Scopus or Web of Science (9). contrasted to the legitimate pathology journals. 


\section{Materials and Methods}

75

\section{Journals Identification and Selection}

Between January and May 2018, Beall's list of predatory journals served as an initial database of suspected journals related to pathology, as it was previously used in other studies $(2,7)$. The term "potential predatory" was only used after assessing each journal separately based on the recommended criteria that are summarized in Table 1 (2, 8). On the other hand, the major bibliographic databases were explored (PubMed/MEDLINE, PubMed Central (PMC), and Web of Science/Science Citation Index (Science Citation Index/Science Citation Index Expanded (SCI/SCIE)) to identify legitimate journals in pathology. The journal titles were retrieved using the following key words: anatomic pathology, cellular pathology, clinical pathology, cytopathology, diagnostic pathology, experimental pathology, histopathology, human pathology, immunopathology, medical pathology, molecular pathology, molecular biomarkers, neuropathology, pathology, and surgical pathology.

\section{Data Collection (phase 1)}

After collecting the available number of journals related to pathology, each journal was assessed based on, Clemson and colleagues' criteria; its indexing status, clarity of peer-review process, availability of its archive, legitimacy of editorial board, the status of International Standard Serial Number (ISSN), emphasis on OA, and country of origin (8).

\subsection{Status of ISSN and country of origin}


To identify the journal's country of origin and the ISSN legitimacy of the suspected journals, the ISSN Portal service was used (available at https://portal.issn.org), which is an online database that provides information about the journal's resource and record including the country of origin.

\subsection{Amount of APCs}

In order to obtain the amount of requested APCs, each journal's web site was checked for the Creative Commons 'Attribution' License Non-Commercial (CC BY-NC) using the currency converter (available at https://xe.com). OA", were labeled under "emphasis on open-access". Editorial boards were reviewed in labeled under "ambiguous or unclear peer-review process".

\subsection{Website integrity, number of issues, and misleading titles}

For the website integrity, marking was based on presence of major design flaws, compatibility and language mistakes. "Unreal or small number of issues per year" was

\subsection{Indexing status}


The indexing status displayed on the journal's website was appraised via both the

National Library of Medicine's (NLM) catalog (available at

\section{Data Collection (phase 2)}

After obtaining preliminary data from phase 1 of the assessment, each journal was misleading titles were obtained in phase 1 , their findings were only reviewed.

\subsection{Aims and scope, home page integrity, and contact information}

The aims and scope were investigated for inclusion of non-biomedical subjects. and non-journal affiliated emails, were all collected.

\subsection{Editorial processing, and publication copyright, ethics and policies}

Presence of editor-in-chief, editorial board, submission system, peer review, retraction, copyright and plagiarism policies, and APC amount, were labeled accordingly.

\subsection{Indexing and impact factor}

The status of each journal was checked in PubMed/Medline, Web of Science (SCI/SCIE), the World Association of Medical Editors (WAME) (available at 

also considered.

\section{Statistical Analysis}




\section{Results}

Of the total current publishers on Beall's list (1196), 69 potential predatory journals were identified in the field of pathology ("the black list" journals). The journals' titles and their respective publishers are shown in Table 2. Only one of the identified potential predatory journals in pathology (Journal of Modern Human Pathology) was indexed in the DOAJ. None of these journals were indexed in PubMed/MEDLINE, Web of Science (SCI/SCIE) nor listed in COPE or had a legitimate impact factor in the JCR (Clarivate Analytics) ("the white list" journals). Of note, 13 potential predatory journals in pathology had at minimum one of their articles archived in the PMC repository (following the policy of PMC as a digital repository archiving free full-text articles that had been published within the biomedical and life science journals). On the other hand, 89 legitimate journals were identified in the field of pathology and used for the comparison (listed in Table 3).

All potential predatory journals in pathology shared at least one common poorquality characteristics: lack of web-site integrity $(\mathrm{n}=21,31 \%)$ vs. $(\mathrm{n}=0 \%$ in OA legitimate), missing/pending ISSN number $(n=36,52 \%)$ vs. $(n=0 \%$ in OA legitimate), unreal or small number of issues per year $(n=22,32 \%)$ vs. $(n=3,3 \%$ in OA legitimate), emphasis on OA policy $(\mathrm{n}=40,58 \%)$ vs. $(\mathrm{n}=32,38 \%$ in OA legitimate $)$, missing editorial board $(n=20,29 \%)$ vs. $(n=1,1 \%$ in OA legitimate), and ambiguous or unclear peer-review process $(n=38,55 \%)$ vs. $(n=12,14 \%$ in OA legitimate $)$. Moreover, the majority $(77 \%)$ of potential predatory journals accepted manuscript submissions via email. Absence of retraction, plagiarism, and copyright policies were all characteristics of the suspected journals as shown in Table 4 and Figure 1. 
Furthermore, $21(30 \%)$ potential predatory journals had misleading titles, which resemble or appear to be tied to those of legitimate ones (see Table 5). In addition, $31 \%$ of the potential predatory journals were indexed in the databases that generate bogus impact factors (e.g. Index Copernicus, Cosmos Impact Factor, and J-Gate). More specifically, $19 \%$ of the potential predatory journals presented their Index Copernicus value, whereas only $4 \%$ of the legitimate journals presented this impact factor. 814.3; range US\$ 550-4100 vs. US\$ 50-2700; $\mathrm{p}<0.001)$. $70 \%$ ) of the targeted journals were originated from the United States, followed by India $10 \%)$, Nigeria $(\mathrm{n}=2,6 \%)$, and the United Arab Emirates $(\mathrm{n}=1,3 \%)$. 


\section{Discussion}

The Internet has dramatically transformed academic publishing, most notably, due to the introduction of OA publishing (2-5). Recently, there has been a rapid rise of online journals described as 'predatory' $(3,4)$. Such journals actively solicit manuscripts and charge publication fees without providing a robust peer review and proper editorial services (e.g. copyediting and proofreading) $(2-4,8,9)$. Yet, it is important to note that OA is not correlated with the legitimacy of the journal.

In the present study, the impact of potential predatory journals in pathology was explored. Similar to other biomedical fields, our data indicate a substantial burden of such journals in academic pathology. One of the important findings of our study is that none of the potential predatory journals in pathology has been indexed in the major bibliographic databases such as PubMed/MEDLINE and Web of Science nor listed in COPE. These results are in line with a recent study on such journals in pediatrics (9). However, the studies in other biomedical fields (neurology/neurosurgery, physical medicine and emergency medicine) revealed the substantial contamination (up to $25 \%$ ) not a predatory-free database $(14,15)$. PubMed indexing policies are less strict compared with MEDLINE (14). In fact, $98 \%$ of the legitimate journals in this study were indexed in 
PubMed are distinctively different databases, using the PubMed search engine queries both databases simultaneously (as well as PubMed Central).

Our study indicates that a substantial proportion $(30 \%)$ of potential predatory journals in pathology may have similar names to the legitimate and renowned pathology journals (Table 5). In addition, predatory publishers usually send spam emails through which they invite authors to contribute to their journals and conferences promising a fasttrack review and publishing (8). Summarized in Table 4 are the key characteristics of predatory journals/publishers (8), which may also guide the pathology researchers/scientists before deciding to submit an article to not well-known/unknown pathology journals (16). line with previous studies in other medical disciplines, this study confirms that the mean of APC of potential predatory journals in pathology was significantly lower than that of legitimate OA journals in pathology ( US\$2837 vs. US\$814) (17). This marked difference along with "easy to publish" spam announcements might be a reason to attract

Although the US and India were the countries of origin for the majority of the some inexperienced and/or young academic pathologists to submit a paper to such journals. potential predatory journals, the methodology used in this paper provides better precision regarding the journal's country of origin. In previous reports, Google Maps and 3D Street View were used predominantly to determine the journals and/or publishers' country of origin based on the addresses displayed in their websites $(7,17)$. Such methodology is not 
credible to assess the country of origin, simply, because any random address can be presented in their web sites.

Notwithstanding its implications, two limitations to this study are important to highlight. First, the use of Beall's list has been controversial as it was discontinued in 2017 and is consequently considered outdated $(18,19)$. Nevertheless, that list served as a start point given that each journal in our study was objectively apprised following the recommended criteria proposed by other researchers (8). Second, the Beall's list was criticized for being subjective as it was established and updated by a single person; however, several well-conducted studies have relied on the list as an accessible reference for predatory journals $(2,6,7,17,18)$. Finally, it is worth mentioning that the removal of Beall's list led to the rise of new alternatives such as Cabell's Blacklist (20). resemblance to the legitimate pathology journals, which may pose another significant challenge and threat to the academic community within this medical discipline. This study may aid pathology researchers in their decision-making process when submitting manuscripts for publication. Based on the obtained data, authors should check the journal's status on PubMed/MEDLINE, Web of Science and DOAJ, as well as the 


\section{Acknowledgment}

This study was supported by the student grant number (\#QUST-1-CMED-201810) provided by the College of Medicine, Qatar University. The preliminary data from the study were presented at the XXXII Congress of the International Academy of Pathology (IAP), October 2018, Amman, Jordan.

253

\section{Conflict of interest}




\section{References}

263 1. Clark J, Smith R. Firm action needed on predatory journals. BMJ. 2015;350:h210.

$2642 . \quad$ Shamseer L, Moher D, Maduekwe O, Turner L, Barbour V, Burch R, et al. Potential predatory and 265 legitimate biomedical journals: can you tell the difference? A cross-sectional comparison. BMC Med.

$266 \quad 2017 ; 15(1): 28$.

267 3. Beall J. Predatory journals: Ban predators from the scientific record. Nature.

268 2016;534(7607):326.

269 4. Beall J. Predatory publishers are corrupting open access. Nature. 2012;489(7415):179.

270 5. Laakso M, Welling P, Bukvova H, Nyman L, Bjork BC, Hedlund T. The development of open access 271 journal publishing from 1993 to 2009. PLoS One. 2011;6(6):e20961.

272 6. Manca A, Martinez G, Cugusi L, Dragone D, Mercuro G, Deriu F. Predatory Open Access in

273 Rehabilitation. Arch Phys Med Rehabil. 2017;98(5):1051-6.

$2747 . \quad$ Manca A, Martinez G, Cugusi L, Dragone D, Dvir Z, Deriu F. The surge of predatory open-access

275 in neurosciences and neurology. Neuroscience. 2017;353:166-73.

276 8. Clemons M, de Costa ESM, Joy AA, Cobey KD, Mazzarello S, Stober C, et al. Predatory Invitations 277 from Journals: More Than Just a Nuisance? The oncologist. 2017;22(2):236-40.

278 9. Kokol P, Zavrsnik J, Zlahtic B, Blazun Vosner H. Bibliometric characteristics of predatory journals 279 in pediatrics. Pediatr Res. 2018.

280 10. Rupp M, Anastasopoulou L, Wintermeyer E, Malhaan D, El Khassawna T, Heiss C. Predatory 281 journals: a major threat in orthopaedic research. Int Orthop. 2018.

282 11. Cortegiani A, Longhini F, Sanfilippo F, Raineri SM, Gregoretti C, Giarratano A. Predatory Open283 Access Publishing in Anesthesiology. Anesth Analg. 2018.

284 12. Hansoti B, Langdorf MI, Murphy LS. Discriminating Between Legitimate and Predatory Open 285 Access Journals: Report from the International Federation for Emergency Medicine Research 286 Committee. The western journal of emergency medicine. 2016;17(5):497-507.

287 13. Di Lena M, Nickel JC. Publish and perish: A urological perspective on predatory publications. Can 288 Urol Assoc J. 2018.

289 14. Manca A, Moher D, Cugusi L, Dvir Z, Deriu F. How predatory journals leak into PubMed. CMAJ. 290 2018;190(35):E1042-E5.

291 15. Manca A, Cugusi L, Dvir Z, Deriu F. PubMed should raise the bar for journal inclusion. Lancet. 292 2017;390(10096):734-5.

293 16. Manca A, Cugusi L, Dragone D, Deriu F. Predatory journals: Prevention better than cure? J

294 Neurol Sci. 2016;370:161.

295 17. Shen C, Bjork BC. 'Predatory' open access: a longitudinal study of article volumes and market 296 characteristics. BMC Med. 2015;13:230.

297 18. Kurt S. Why do authors publish in predatory journals? Learned Publishing. 2018;31(2):141-7.

298 19. Singh Chawla D. The undercover academic keeping tabs on 'predatory' publishing. Nature.

299 2018;555(7697):422-3.

$30020 . \quad$ Strielkowski W. Predatory Publishing: What Are the Alternatives to Beall's List? Am J Med.

301 2018;131(4):333-4.

302 


\section{Tables}

Table 1: Features of potential predatory journal as proposed by Clemons et al. and

\section{Features}

1 Set up journal names and websites that resemble or appear to be tied to those of legitimate ones

2 Wide scope of interest covering biomedical and non-biomedical subjects

3 Having spelling and grammar mistakes in the website

$4 \quad$ Displayed images are usually distorted and fuzzy

5 The website homepage language targets authors

6

Stating plans for indexing in reputable databases such as PubMed, while emphasizing being indexed in Index Copernicus.

7 Unreal number of issues per year, missing or pending ISSN number

8 Absent and/or unclear peer-review process

$9 \quad$ Manuscripts are submitted via email

10 Fast publication is assured

11 Absence of retraction and/or copyright policies

12 Lack of journal archive and/or digital preservation of content.

13 Low APCs (Article Processing Charges)

Personalized spam emails targeting a variety of authors inviting them to contribute with short

14 deadlines

15 The contact email is non-journal affiliated (e.g., @hotmail.com) 
Table 2: A list of potential predatory journals in pathology $(n=69)$

\begin{tabular}{|c|c|c|}
\hline & Journal & Publisher \\
\hline 1 & $\begin{array}{l}\text { Academic Open Clinical Pathology Research } \\
\text { Journal }\end{array}$ & Academic Knowledge and Research Publishing \\
\hline 2 & Advanced Journal of Surgical Pathology & Advanced Scholars Journals \\
\hline 3 & African Journal of Cellular Pathology & Clavenanum Press Nigeria Limited \\
\hline 4 & Allied Journal of Clinical Pathology Research & Allied Academies \\
\hline 5 & American Research Journal of Pathology & American Research Journals \\
\hline 6 & Annals of Clinical Pathology Research & Remedy Publications \\
\hline 7 & Annals of Clinical Pathology & JSciMed Central \\
\hline 8 & Archives of Pathology and Clinical Research & Heighten Science Publications \\
\hline 9 & Archives of Clinical Pathology & SciTechnol \\
\hline 10 & Asian American Pathology Research Journal & $\begin{array}{l}\text { Asian and American Research Publishing } \\
\text { Group }\end{array}$ \\
\hline 11 & Austin journal of clinical pathology & Austin Publishing Group \\
\hline 12 & $\begin{array}{l}\text { Austin Journal of Pathology \& Laboratory } \\
\text { Medicine }\end{array}$ & Austin Publishing Group \\
\hline 13 & $\begin{array}{l}\text { Journal of Clinical Pathology and Forensic } \\
\text { Medicine }\end{array}$ & Academic Journals \\
\hline 14 & BAOJ Pathology and Clinical Research & Bio Accent \\
\hline 15 & British Open Journal of Pathology & British Open Research Publications \\
\hline 16 & Canadian Open Clinical Pathology Journal & Canadian Research Publication \\
\hline 17 & Case Reports in Clinical Pathology & Sciedu Press \\
\hline 18 & Journal of Clinical and Diagnostic Pathology & Open Access Pub \\
\hline 19 & $\begin{array}{l}\text { International Journal of Clinical } \\
\text { and Experimental Pathology }\end{array}$ & e-Century Publishing Corporation \\
\hline 20 & Clinical and Diagnostic Pathology & Open Access Text (OAT, OA Text) \\
\hline 21 & Journal of Clinical \& Experimental Pathology & OMICS International \\
\hline
\end{tabular}




\begin{tabular}{|c|c|c|}
\hline 22 & CRESSCO International Journal of Pathology & Cresco Online Publishing \\
\hline 23 & Current Updates in Clinical Pathology & OPR Science \\
\hline 24 & Developments in Clinical \& Medical Pathology & Crimson Publishers \\
\hline 25 & Diagnostic Pathology: Open Access & OMICS International \\
\hline 26 & $\begin{array}{l}\text { Donnish Journal of Clinical Pathology and } \\
\text { Forensic Medicine }\end{array}$ & Donnish Journals \\
\hline 27 & Eurasian Clinical Pathology Research Journal & Eurasian Research Publishing \\
\hline 28 & European Open Clinical Pathology Journal & European Union Research Publishing \\
\hline 29 & $\begin{array}{l}\text { Global Scientific Research Journal of } \\
\text { Pathology }\end{array}$ & Global Scientific Research Journals (GSR) \\
\hline 30 & $\begin{array}{l}\text { HSOA Journal of Pathology Clinical \& } \\
\text { Medical Research }\end{array}$ & Herald Scholarly Open Access \\
\hline 31 & Immunochemistry \& immunopathology & OMICS International \\
\hline 32 & Integrative Clinical Pathology & Scient Open Access \\
\hline 33 & International clinical pathology journal & MedCrave \\
\hline 34 & $\begin{array}{l}\text { International Journal of Clinical Pathology and } \\
\text { Diagnosis }\end{array}$ & Gavin Publishers \\
\hline 35 & $\begin{array}{l}\text { International Journal of Clinical Pathology } \\
\text { Research }\end{array}$ & Academic and Scientific Publishing \\
\hline 36 & $\begin{array}{l}\text { International Journal of Microbiology and } \\
\text { Pathology }\end{array}$ & OMICS International \\
\hline 37 & Journal of Speech Pathology \& Therapy & OMICS International \\
\hline 38 & $\begin{array}{l}\text { International Journal of Pathology and Clinical } \\
\text { Research }\end{array}$ & ClinMed International Library \\
\hline 39 & $\begin{array}{l}\text { International Journal of Pathology Research } \\
\text { and Practice }\end{array}$ & Axis Journals \\
\hline 40 & $\begin{array}{l}\text { IP Journal of Diagnostic Pathology and } \\
\text { Oncology }\end{array}$ & Innovative Publication \\
\hline 41 & The open forensic science journal & Bentham Open \\
\hline 42 & Journal of Cellular \& Molecular Pathology & Insight Medical Publishing (IMedPub) \\
\hline
\end{tabular}




\begin{tabular}{|c|c|c|}
\hline 43 & Journal of Clinical \& Anatomic Pathology & JScholar Journals \\
\hline 44 & Journal of Clinical \& Experimental Pathology & OMICS International \\
\hline 45 & Journal of Clinical Pathology and Cytology & Bio Accent \\
\hline 46 & Journal of Immunopathology & Pulsus Group \\
\hline 47 & Journal of Medical \& Surgical Pathology & OMICS International \\
\hline 48 & $\begin{array}{l}\text { Journal of Medicine, Radiology, Pathology and } \\
\text { Surgery }\end{array}$ & $\begin{array}{l}\text { Incessant Nature Science Publishers } \\
\text { (INSPublishers) }\end{array}$ \\
\hline 49 & Journal of modern human pathology & NobleResearch \\
\hline 50 & Journal of Molecular Biomarkers \& Diagnosis & OMICS International \\
\hline 51 & $\begin{array}{l}\text { Journal of MPE Molecular Pathological } \\
\text { Epidemiology }\end{array}$ & Insight Medical Publishing (IMedPub) \\
\hline 52 & Journal of Pathology and Therapeutics & Sci Forschen \\
\hline 53 & Pathology and Laboratory Medicine & Science Publishing Group \\
\hline 54 & $\begin{array}{l}\text { North American Open Clinical Pathology } \\
\text { Research Journal }\end{array}$ & North American Research Publishing \\
\hline 55 & $\begin{array}{l}\text { North American Open Physiology \& } \\
\text { Pathophysiology Research Journal }\end{array}$ & North American Research Publishing \\
\hline 56 & Open Journal of Pathology & Scientific Research Publishing (SCIRP) \\
\hline 57 & $\begin{array}{l}\text { Pathology and Laboratory Medicine - Open } \\
\text { Journal (PLMOJ) }\end{array}$ & Openventio Publishers \\
\hline 58 & Pathology Discovery & Herbert Open Access Journals \\
\hline 59 & International Journal of Ophthalmic Pathology & SciTechnol \\
\hline 60 & $\begin{array}{l}\text { Recent Advances in Pathology \& Laboratory } \\
\text { Medicine (RAPL) }\end{array}$ & Advanced Research Publications \\
\hline 61 & Reports in Disease Markers & OMICS International \\
\hline 62 & Saudi Journal of Pathology and Microbiology & Scholars Middle East Publishers \\
\hline 63 & $\begin{array}{l}\text { Swift Journal of Clinical Pathology and } \\
\text { Forensic Medicine }\end{array}$ & Swift Journals \\
\hline 64 & The Internet Journal of Pathology & Internet Scientific Publications \\
\hline 65 & TJPRC: Journal of Human Pathology \& & Trans Stellar \\
\hline
\end{tabular}


bioRxiv preprint doi: $\mathrm{https}$ //doi.org/10.1101/482174; this version posted December 4,2018 . The copyright holder for this preprint (which was not certified by peer review) is the author/funder, who has granted bioRxiv a license to display the preprint in perpetuity. It is made available under aCC-BY-NC-ND 4.0 International license.

\begin{tabular}{|l|l|l|}
\hline & Research & \\
\hline 66 & $\begin{array}{l}\text { Universal Open Forensic Medicine and } \\
\text { Pathology Journal }\end{array}$ & Adyan Academic Press \\
\hline 67 & Universal Open Pathogens Journal & Adyan Academic Press \\
\hline 68 & US Open Clinical Pathology Journal & American Research Publications \\
\hline 69 & World journal of pathology & Narain Publishers Pvt. Ltd (NPPL) \\
\hline 10 & & \\
\hline
\end{tabular}


Table 3: A list of Legitimate Journals in pathology $(n=89)$

\begin{tabular}{|c|c|c|}
\hline & Journal & Publisher \\
\hline 1 & Academic Pathology & Sage Publications \\
\hline 2 & Acta Neuropathologica & Springer \\
\hline 3 & Advances in Anatomic Pathology & Lippincott Williams \& Wilkins \\
\hline 4 & Alzheimer Disease \& Associated Disorders & Lippincott Williams \& Wilkins \\
\hline 5 & The American Journal of Clinical Pathology & Oxford Academic \\
\hline 6 & $\begin{array}{l}\text { The American Journal of Forensic Medicine } \\
\text { and Pathology }\end{array}$ & Lippincott Williams \& Wilkins \\
\hline 7 & The American Journal of Pathology & Elsevier \\
\hline 8 & The American Journal of Surgical Pathology & Wolters Kluwer Health \\
\hline 9 & Analytical Cellular Pathology & Hindawi Publishing Corporation \\
\hline 10 & Annales de Pathologie & Elsevier \\
\hline 11 & Annals of Diagnostic Pathology & Elsevier \\
\hline 12 & $\begin{array}{l}\text { Annual Review of Pathology-Mechanisms of } \\
\text { Disease }\end{array}$ & Annual Reviews \\
\hline 13 & APMIS & Wiley \\
\hline 14 & $\begin{array}{l}\text { Applied Immunohistochemistry \& Molecular } \\
\text { Morphology }\end{array}$ & Lippincott Williams \& Wilkins \\
\hline 15 & Archives of Pathology \& Laboratory Medicine & College of American Pathologists \\
\hline 16 & BMC Clinical Pathology & BioMed Central \\
\hline 17 & Brain Pathology & Wiley \\
\hline 18 & Brain Tumor Pathology & Springer \\
\hline 19 & Cancer Cytopathology & Wiley \\
\hline 20 & Cardiovascular Pathology & Elsevier \\
\hline 21 & Case Reports in Pathology & Hindawi Publishing Corporation \\
\hline 22 & Cellular Oncology & Springer \\
\hline 23 & Clinical Medicine Insights: Pathology & Sage Publications \\
\hline 24 & Clinical Neuropathology & Dustri-Verlag \\
\hline 25 & CytoJournal & Medknow Publications \\
\hline
\end{tabular}




\begin{tabular}{|c|c|c|}
\hline 26 & Cytometry Part B: Clinical Cytometry & Wiley \\
\hline 27 & Cytopathology & Wiley \\
\hline 28 & Diagnostic Cytopathology & Wiley \\
\hline 29 & Diagnostic Histopathology & Elsevier \\
\hline 30 & Diagnostic Pathology & BioMed Central \\
\hline 31 & Disease Markers & Hindawi Publishing Corporation \\
\hline 32 & Disease Models \& Mechanisms & Cambridge \\
\hline 33 & Endocrine Pathology & Springer \\
\hline 34 & Experimental and Molecular Pathology & Elsevier \\
\hline 35 & Experimental and Toxicologic Pathology & Elsevier \\
\hline 36 & Expert Review of Molecular Diagnostics & Taylor \& Francis Online \\
\hline 37 & Fetal and Pediatric Pathology & Taylor \& Francis Online \\
\hline 38 & Folia Neuropathologica & Termedia \\
\hline 39 & Forensic Science Medicine and Pathology & Springer \\
\hline 40 & Histology and Histopathology & Histology and Histopathology \\
\hline 41 & Histopathology & Wiley \\
\hline 42 & HLA & Wiley \\
\hline 43 & Human Pathology & Elsevier \\
\hline 44 & Human Pathology: Case Reports & Medknow Publications \\
\hline 45 & Indian Journal of Pathology and Microbiology & Medknow Publications \\
\hline 46 & $\begin{array}{l}\text { International Journal of Experimental } \\
\text { Pathology }\end{array}$ & Wiley \\
\hline 47 & $\begin{array}{l}\text { International Journal of Gynecological } \\
\text { Pathology }\end{array}$ & Dan Pasquarello \\
\hline 48 & $\begin{array}{l}\text { International Journal of Immunopathology and } \\
\text { Pharmacology }\end{array}$ & Biomedical Research Press \\
\hline 49 & International Journal of Surgical Pathology & Sage Publications \\
\hline 50 & ISRN Pathology & Hindawi Publishing Corporation \\
\hline 51 & Journal of Clinical Pathology & BMJ Publishing Group \\
\hline 52 & Journal of Comparative Pathology & Elsevier \\
\hline
\end{tabular}




\begin{tabular}{|c|c|c|}
\hline 53 & Journal of Cutaneous Pathology & Wiley \\
\hline 54 & Journal of Hematopathology & Springer \\
\hline 55 & The Journal of Molecular Diagnostics & Elsevier \\
\hline 56 & $\begin{array}{l}\text { Journal of Neuropathology \& Experimental } \\
\text { Neurology }\end{array}$ & Oxford University Press \\
\hline 57 & Journal of Oral Pathology \& Medicine & Wiley \\
\hline 58 & The Journal of Pathology & Wiley \\
\hline 59 & $\begin{array}{l}\text { Journal of Pathology and Translational } \\
\text { Medicine }\end{array}$ & The Korean Society of Pathologists \\
\hline 60 & Journal of Pathology Informatics & Medknow Publications \\
\hline 61 & Journal of Toxicologic Pathology & Japanese Society of Toxicologic Pathology \\
\hline 62 & Laboratory Investigation & Nature \\
\hline 63 & Leprosy Review & Lepra \\
\hline 64 & Malaysian Journal of Pathology & Academy of Medicine of Malyasia \\
\hline 65 & Medical Molecular Morphology & Springer \\
\hline 66 & Modern Pathology & Nature \\
\hline 67 & Neuropathology & Wiley \\
\hline 68 & Neuropathology and Applied Neurobiology & Wiley \\
\hline 69 & Pathobiology & Karger Publishers \\
\hline 70 & Der Pathologe & Springer \\
\hline 71 & Pathologie Biologie & Elsevier \\
\hline 72 & Pathology & Elsevier \\
\hline 73 & Pathology \& Oncology Research & Springer \\
\hline 74 & $\begin{array}{l}\text { Pathology and Laboratory Medicine } \\
\text { International }\end{array}$ & Dove Press \\
\hline 75 & Pathology International & Wiley \\
\hline 76 & Pathology Research and Practice & Elsevier \\
\hline 77 & Pathology Research International & Hindawi Publishing Corporation \\
\hline 78 & Patologîâ & Elsevier \\
\hline 79 & Pediatric and Developmental Pathology & Sage Publications \\
\hline
\end{tabular}




\begin{tabular}{|l|l|l|}
\hline 80 & Polish Journal of Pathology & Termedia \\
\hline 81 & Science \& Justice & Elsevier \\
\hline 82 & Seminars in Diagnostic Pathology & Elsevier \\
\hline 83 & Seminars in Immunopathology & Springer \\
\hline 85 & Tissue Antigens & Wiley \\
\hline 86 & Toxicologic Pathology & Wiley \\
\hline 87 & Ultrastructural Pathology & Sage Publications \\
\hline 88 & Veterinary Pathology & Taylor \& Francis Online \\
\hline 89 & Virchows Archiv & Sage Publications \\
\hline
\end{tabular}


Table 4: A comparison of key characteristics of potential predatory journals/publishers in

\begin{tabular}{|c|c|c|c|}
\hline & Criteria & $\begin{array}{c}\text { Potential } \\
\text { predatory* } \\
\mathrm{N}=69, \mathrm{n}(\%)\end{array}$ & $\begin{array}{l}\text { Legitimate* } \\
\mathbf{N}=\mathbf{8 5}, \mathbf{n}(\%)\end{array}$ \\
\hline & Scope of interest: & & \\
\hline Aims and scope & a) Biomedical & $65(94)$ & $82(96)$ \\
\hline & b) Biomedical \& non-biomedical & $2(3)$ & $3(4)$ \\
\hline $\begin{array}{l}\text { Journal name and } \\
\text { publisher }\end{array}$ & Title similar to legitimate journal & $21(30)$ & \\
\hline & $\begin{array}{l}\text { The website contains spelling and/or } \\
\text { grammar errors }\end{array}$ & $19(28)$ & $3(4)$ \\
\hline & Distorted and/or fuzzy images & $17(25)$ & $2(2)$ \\
\hline Home page integrity & Type of users targeted by homepage langl & ge: & \\
\hline & a) Author & $46(67)$ & $67(79)$ \\
\hline & b) General & $21(30)$ & $18(21)$ \\
\hline Contact information & $\begin{array}{l}\text { The contact email address is non-journal } \\
\text { affiliated (e.g., @ hotmail.com) }\end{array}$ & $9(13)$ & $2(2)$ \\
\hline & Index Copernicus value & $13(19)$ & $3(4)$ \\
\hline & PubMed indexed & $0(0)$ & $83(98)$ \\
\hline & Medline indexed & $0(0)$ & $69(81)$ \\
\hline Indexing and impact & DOAJ indexed & $1(1)$ & $19(22)$ \\
\hline factor & ISSN identified & $33(48)$ & $85(100)$ \\
\hline & WAME listed & $0(0)$ & $1(1)$ \\
\hline & COPE listed & $0(0)$ & $63(74)$ \\
\hline & Named editor-in-chief & $34(49)$ & $84(99)$ \\
\hline & Named editorial board & $49(71)$ & $84(99)$ \\
\hline $\begin{array}{l}\text { Editorial processing and } \\
\text { peer review }\end{array}$ & $\begin{array}{l}\text { Description of manuscript handling } \\
\text { process }\end{array}$ & $27(39)$ & $82(96)$ \\
\hline & Submission system: & & \\
\hline & a) E-mail & $53(77)$ & $0(0)$ \\
\hline
\end{tabular}


bioRxiv preprint doi: https://doi.org/10.1101/482174; this version posted December 4, 2018. The copyright holder for this preprint (which was not certified by peer review) is the author/funder, who has granted bioRxiv a license to display the preprint in perpetuity. It is made available under aCC-BY-NC-ND 4.0 International license.

\begin{tabular}{|l|l|l|l|}
\hline & \multicolumn{1}{|c|}{ b) Journal submission system } & $45(65)$ & $85(100)$ \\
\hline & $\begin{array}{l}\text { Rapid publication is promised } \\
\text { States using peer-review }\end{array}$ & $12(17)$ & $0(0)$ \\
\hline $\begin{array}{l}\text { Publication ethics and } \\
\text { policies }\end{array}$ & $\begin{array}{l}\text { Lack of retraction policy } \\
\text { Presence of plagiarism policy }\end{array}$ & $64(93)$ & $85(100)$ \\
\hline \multirow{3}{*}{$\begin{array}{l}\text { Publication model and } \\
\text { copyright }\end{array}$} & $\begin{array}{l}\text { Digital preservation of content } \\
\text { APC amount: }\end{array}$ & $43(62)$ & $18(21)$ \\
\hline & a) Stated & $42(61)$ & $85(100)$ \\
\hline & Retain copyright of published articles: & & $83(98)$ \\
\hline & a) Stated & $57(83)$ & $2(2)$ \\
\hline & b) Not found & $37(54)$ & $77(91)$ \\
\hline
\end{tabular}

*Open access journals

317

318 
Table 5: Potential predatory journals in pathology $(n=21)$ with names resembling/overlapping with those of the legitimate pathology journals

\section{Predatory}

1. Journal of Modern Human Pathology

2. TJPRC: Journal of Human Pathology \& Research

3. Case Reports in Clinical Pathology

4. International Journal of Pathology

Research and Practice

\section{Legitimate}

Human Pathology

Modern Pathology

American Journal of Pathology

Case Reports in Pathology

Pathology Research and Practice

Pathology and Oncology Research

5. Archives of Pathology and Microbiology

6. Archives of Pathology and Clinical Research

Archives of Pathology \& Laboratory Medicine

7. Pathology and Laboratory Medicine Open Journal

8. Diagnostic Pathology: Open Access

9. Clinical and Diagnostic Pathology

Diagnostic Pathology

10. Journal of Clinical \& Experimental Pathology

11. International Journal of Clinical and International Journal of Experimental Pathology Experimental Pathology

12. International Journal of Pathology and Clinical Research

13. Open Journal of Pathology Journal of Pathology

14. World Journal of Pathology Pathology

15. Journal of Clinical \& Anatomic Pathology

American Journal of Clinical Pathology

16. Reports in Disease Markers Disease Markers

17. Case Reports in Clinical Pathology

Human Pathology: Case Reports 
bioRxiv preprint doi: https://doi.org/10.1101/482174; this version posted December 4,2018 . The copyright holder for this preprint (which was not certified by peer review) is the author/funder, who has granted bioRxiv a license to display the preprint in perpetuity. It is made available under aCC-BY-NC-ND 4.0 International license.

18. Journal of Medical \& Surgical Pathology

19. Advanced Journal of Surgical Pathology

International Journal of Surgical Pathology

20. Austin journal of clinical pathology

21. US Open Clinical Pathology Journal

Journal of Clinical Pathology

321

322

323 
bioRxiv preprint doi: https://doi.org/10.1101/482174; this version posted December 4 , 2018. The copyright holder for this preprint (which was not certified by peer review) is the author/funder, who has granted bioRxiv a license to display the preprint in perpetuity. It is made available under aCC-BY-NC-ND 4.0 International license.

Figures

325

Figure 1: A comparison of quality characteristics among the pathology journals.

326

327

328 
Retain copyright of pubsished articles

Presence of plagiarism policy

Rapid publicaxion is promised

Unreal of small number of issues per year

copt listed

COA indered

Medline indered

Publed indered

Index Copernicus value

Ambiguous of undear pettreview process

Suberission via emal

Missing names of editorial board members

Missing/pending ISSN number

Distorted and/or furry images

Having speting and/or grammar enrors in the website
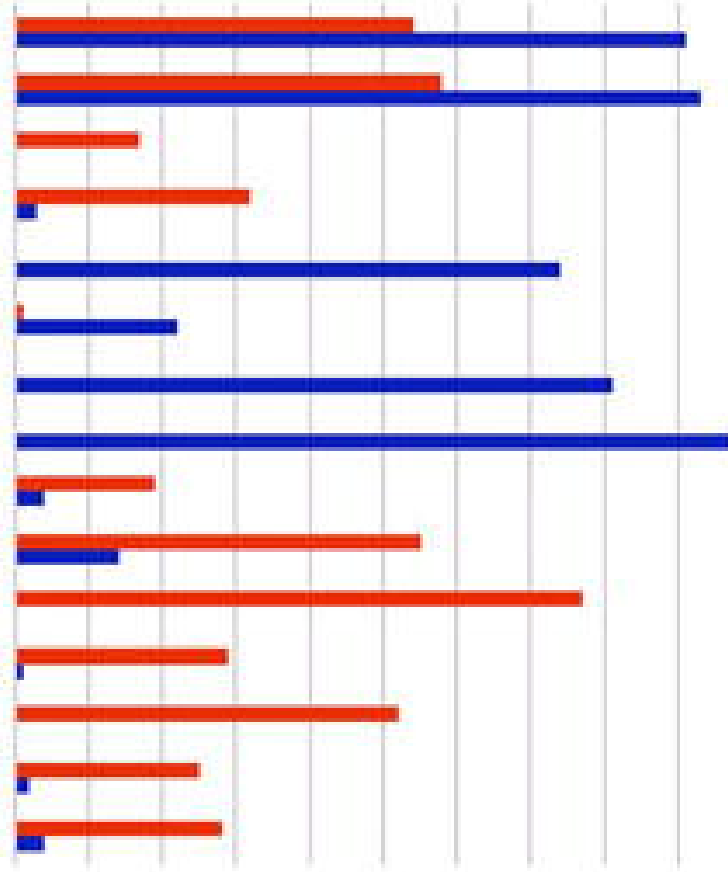

ok

$10 \%$

$20 \% 30 \% 40 \%$

$50 \% 60 \%$ 